\title{
Cuba, a Tricontinental e o Movimento Negro estadunidense: algumas reflexões sobre os caminhos da solidariedade (1966-1974)
}

\author{
Lidia Maria de Abreu Generoso ${ }^{1}$ \\ Taciana Almeida Garrido de Resende ${ }^{2}$
}

\begin{abstract}
Resumo: A Organização de Solidariedade dos povos de África, Ásia e América Latina (OSPAAAL), criada em 1966 e sediada em Havana, certamente contribuiu para intensificar as conexões que floresciam entre a Revolução Cubana e os Movimentos Negros estadunidense ao longo das décadas de 1960 e 1970. A revista Tricontinental - porta-voz da organização publicou resoluções, cartazes, capas, entrevistas, discursos e artigos, divulgando as lutas por libertação negra nos EUA ao redor do globo. O governo cubano, por sua vez, adotava uma política externa enfática no apoio às pautas antirracistas no plano internacional e, ao mesmo tempo, cerceava o debate sobre as relações raciais no interior da ilha. Este trabalho tem como objetivo compreender de que modo se estabeleceram as conexões, rede

s e itinerários descritos acima, analisar as principais estratégias políticas e discursivas adotadas por esses grupos e, enfim, refletir acerca dos desafios da construção da solidariedade internacional.
\end{abstract}

Palavras-chave: Cuba; Movimento Negro; revista Tricontinental.

\section{Cuba, the Tricontinental and the US Black Movement: some reflections on the paths of solidarity (1966-1974)}

\begin{abstract}
Organización de Solidaridad de los pueblos de Africa, Asia y America Latina (OSPAAAL) was founded in 1966, with headquarters in Havana, and certainly contributed to intensify the already flourishing relations between the Cuban Revolution and U.S. Black Liberation movements in the 1960s and 70s. The Tricontinental magazine OSPAAAL's official publication - printed resolutions, posters, covers, interviews, speeches and articles disseminating the anti-racist struggles in the U.S. across the globe. The Cuban government, a decisive protagonist in OSPAAAL's work, adopted a foreign policy that was emphatic in its support for anti-racist activism in the international sphere while, however, restricting the debate on racial relations within the island. This paper aims to better comprehend the connections, networks and itineraries described above, analyze the main political and discursive strategies adopted by these groups and, ultimately, reflect on challenges to the construction of solidarity.
\end{abstract}

Keywords: Cuba; Black Liberation; Tricontinental magazine.

\footnotetext{
${ }^{1}$ Doutoranda em História.Universidade Federal de Ouro Preto. Rua Augusta Bittencourt de Oliveira, n. 3, bairro Pilar, Ouro Preto, MG. CEP: 35400-000. Email: generosolidia@gmail.com

2 Mestre em História. Instituto Federal de Minas Geraiss. Rua Ponte Nova, 190 (casa 1), Bairro Colégio Batista, Belo Horizonte, MG. CEP: 31110-150 Email: tacianagarrido@gmail.com
}

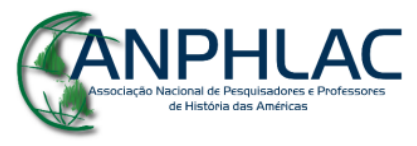

Revista Eletrônica da ANPHLAC, ISSN 1679-1061, No 27, p.222 -256, Ago./, Dez., 2019. http://revista.anphlac.org.br 
Artigo recebido em: 30/06/2019

Artigo aprovado para publicação em: 18/10/2019

\section{Introdução}

Em 1969, o então conselheiro de segurança nacional dos Estados Unidos no governo de Richard Nixon, Henry Kissinger, na ocasião de uma conversa com o chanceler chileno Gabriel Valdés, afirmou:

Nada importante pode vir do Sul. A história nunca foi feita no Sul. O eixo da história começa em Moscou, vai para Bonn, cruza Washington e então para Tóquio. O que acontece no Sul não tem nenhuma importância. ${ }^{3}$ (KISSINGER apud GILDERHUS, 1999, p. 195)

Dez anos depois, Kenneth Waltz (1979, p. 73), um dos mais importantes teóricos realistas das Relações Internacionais, afirmou em seu mais famoso livro: "Seria ridículo construir uma teoria de política internacional baseada na Malásia ou na Costa Rica. Uma teoria geral é necessariamente baseada nas grandes potências".

A dinâmica dessas relações, porém, começou a sofrer seus primeiros reveses no século $\mathrm{XX}$, diante de articulações políticas no âmbito internacional. O V Congresso Pan-Africano em Manchester, a conferência afro-asiática de Bandung, o I Congresso de Escritores e Artistas Negros, em Paris, a criação da Organização da Unidade Africana, em Addis Abeba, e a realização, em Cuba, de reuniões como a Conferência Tricontinental e a primeira conferência da Organização Latino-Americana de Solidariedade, por exemplo, foram alguns dos encontros que modificaram a tradicional conformação política mundial. A porta de entrada das Relações Internacionais estava sendo forçada por novos atores, que se articulavam em novos formatos e discursos. A palavras de Fanon (1968, p. 80), publicadas em Condenados da Terra, seriam postas à prova: "não devemos aceitar essas condições. Temos que recusar categoricamente a situação a que nos querem condenar os países ocidentais. O colonialismo e o imperialismo não estão quites conosco por terem retirado de nossos territórios suas bandeiras [...]”.

\footnotetext{
${ }^{3}$ Todas as traduções do inglês e do espanhol apresentadas são de responsabilidade das autoras.
}

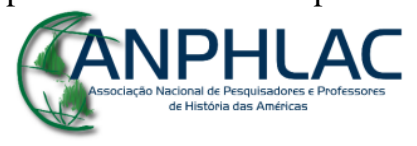

Revista Eletrônica da ANPHLAC, ISSN 1679-1061, N 27, p.222 -256, Ago./, Dez., 2019. http://revista.anphlac.org.br 
Muitos desses encontros tiveram lugar em fins da década de 1950 e durante toda a década seguinte, característica que não deve ser analisada como acidental. A pesquisadora argentina Claudia Gilman afirma que, durante a década de 1960,

a revolução cubana, a descolonização africana, a guerra do Vietnam, a rebelião
antirracista nos Estados Unidos e os diversos surtos de rebeldia juvenil permitem
aludir ao hall de relações institucionais, políticas, sociais e econômicas fora das quais
é difícil pensar como poderia haver surgido a percepção de que o mundo estava prestes
a mudar [...]. (GILMAN, 2003, p. 37)

A confiança na iminência de grandes mudanças foi sensível em vários momentos desse período histórico. As décadas de 1960 e 70 conferiram aos três continentes do então chamado Terceiro Mundo considerável centralidade, não só entre as esquerdas, mas como principal palco dos conflitos da Guerra Fria (YOUNG, 2005). Conforme proposto por Gilman, os anos sessenta e setenta são entendidos aqui como época, não restritos à fixidez de marcos cronológicos. Foram décadas que moldaram certezas de que as últimas independências da África e a vitória do Vietnã produziriam um conjunto de processos irreversíveis no mundo e de que o Terceiro Mundo seria o seu principal protagonista. Na mesma linha interpretativa, o pesquisador britânico Frederick Jameson (1984) localiza na metade da década de 1970 o momento em que essas certezas cederam lugar à realidade de guerras civis na África, ao crescente endividamento dos países do Sul e ao recrudescimento de governos autoritários na América Latina, o que representou o ocaso da confiança e das expectativas para o futuro.

As certezas das décadas de sessenta e setenta conferiram ao período, portanto, sua singularidade. A despeito do que pensavam Kissinger ou Waltz, outras propostas políticas eram gestadas fora do eixo Moscou-Bonm-Washington-Tóquio. Em 1966, ocorreu em Cuba, na cidade Havana, a Conferência Tricontinental, encontro que reuniu representantes da África, Ásia e América Latina com o intuito de construir bases alternativas para o estabelecimento de relações de cooperação e solidariedade diante do impositivo cenário da Guerra Fria. Dentre as propostas aprovadas pelas delegações presentes na Conferência Tricontinental, é fundamental destacar a criação da Organização de Solidariedade dos povos de África, Ásia e América Latina (OSPAAAL), responsável por implementar as resoluções aprovadas na ocasião. Meses depois, entra em cena a revista Tricontinental, publicação oficial da organização com o objetivo de

\section{CANPHLAC}

Revista Eletrônica da ANPHLAC, ISSN 1679-1061, № 27, p.222 -256, Ago./, Dez., 2019. http://revista.anphlac.org.br 
produzir e difundir conteúdo informativo, político e cultural e impulsionar as lutas e a solidariedade entre os "condenados da Terra".

Este artigo parte do entendimento de que a Tricontinental de Havana, em 1966, na esteira da Política dos Encontros ${ }^{4}$ inaugurada em Bandung, foi responsável pela consolidação de uma nova "cartografia discursiva" que privilegiava as ideias e as histórias compartilhadas pelo Terceiro Mundo (GRONBECK-TEDESCO, 2008, p. 653). Após as primeiras investidas de solidariedade entre os países afro-asiáticos na década de 1950, o evento em Cuba somou a América Latina à ação internacional do Terceiro Mundo e serviu para que o próprio governo de Fidel Castro reivindicasse o lugar de porta-voz de uma nova "política tricontinental", que apresentava a ilha como um modelo de igualdade social e racial a ser seguido e alcançado (GRONBECK-TEDESCO, 2008, p. 651).

A revista homônima ao encontro, criada e administrada pela OSPAAAL, ecoou pelas décadas seguintes essa premissa e fortificou os laços entre as redes intelectuais do Sul. Parte importante dos diálogos apoiados e divulgados pela Revista Tricontinental se estabeleceram com os representantes de movimentos pelos direitos civis nos Estados Unidos, intelectuais afroamericanos em sua maioria, alargando assim as próprias barreiras do então chamado Terceiro Mundo.

A partir da década de 1960, a linha mestra da política externa cubana foi divulgar a experiência socialista como modelo internacional a ser seguido pelas esquerdas e a realização da Conferência Tricontinental em Havana, em 1966, se insere nesse esforço. Na ocasião, o país se engajou em receber representantes oficiais de governos, movimentos de libertação nacional, além de grupos e partidos ligados às aspirações das esquerdas nos três continentes. A união de tantas bandeiras em um único lugar, com o questionamento comum ao colonialismo, à legitimidade do imperialismo estadunidense no mundo, e até mesmo ao protagonismo soviético entre os países socialistas, ganhou repercussão internacional e abasteceu as expectativas do

\footnotetext{
${ }^{4}$ Por "Política dos Encontros" entendemos um repertório de práticas empreendidas pelo Terceiro Mundo a partir da ocupação e subversão de espaços oficiais antes reservados ao imperialismo e ao colonialismo. O reconhecimento do valor e da potência das trocas internacionais, a afirmação de um não alinhamento - ou o alinhamento sob condições de interlocução e o trânsito das teorias do desenvolvimento e do subdesenvolvimento formaram o terreno fértil onde se sedimentou a certeza de que a Política dos Encontros valia a pena como aposta e de que países e povos, cada qual com suas especificidades, poderiam conviver, articular e criar suas próprias saídas.
}

\section{CANPHLAC}

Revista Eletrônica da ANPHLAC, ISSN 1679-1061, № 27, p.222 -256, Ago./, Dez., 2019. http://revista.anphlac.org.br 
governo cubano de se lançar como baluarte da igualdade social - e também racial - entre os povos no mundo.

O cientista político estadunidense Mark Sawyer (2006, p. 64), no livro Racial Politics in Post-Revolutionary Cuba, argumenta que o internacionalismo cubano esteve a serviço da ideologia racial e permitiu à "Cuba revolucionária externalizar problemas raciais e a luta contra o racismo", desviando o foco das incongruências ou incapacidades de sanar a questão dentro da própria ilha. Alguns episódios serviram especialmente a esse intuito, como a saída da delegação diplomática cubana do luxuoso Shelbourne Hotel para o Hotel Theresa, no coração do bairro negro do Harlem, durante a $15^{\text {a }}$ Assembleia Geral das Nações Unidas, em 1960, em Nova York.

Tendo a afirmação de Sawyer como ponto de partida interrogativo para o nosso trabalho, e compreendendo a revista Tricontinental como parte essencial da política - e do discurso antirracista e antirracial do governo cubano, propusemo-nos a examinar e questionar a divulgação que esse periódico publicado em Cuba fez do movimento negro estadunidense. Nosso objetivo é contribuir para a compreensão das complexas, ambíguas, e até mesmo contraditórias relações, entre as políticas interna e a política externa do governo cubano para as relações raciais naquele país. Para isso, analisaremos parte do material publicado pela revista Tricontinental no período que se estende de 1967, data de publicação de seu primeiro número, ao ano de 1974. Consideramos que esse foi o período durante o qual o movimento negro estadunidense obteve maior proeminência na publicação, ainda que essa participação nunca tenha desaparecido. Discursos oficiais do governo cubano e atas da Conferência Tricontinental de Havana também foram consultadas para fortalecer a pesquisa e o argumento aqui defendido. A maior parte dessa documentação se encontra nos arquivos da OSPAAAL, em Havana, onde foi consultada.

\section{Cuba, a questão racial e a política externa pós-1959}

O lugar das questões raciais em Cuba e nas páginas da Tricontinental se apresenta de maneira ambígua e complexa. Por um lado, políticas públicas contra a desigualdade na ilha, como a universalização do ensino básico e os esforços pela universalização do ensino superior,

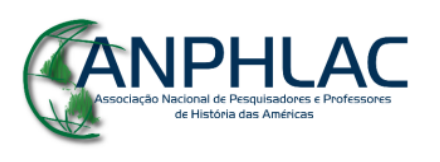

Revista Eletrônica da ANPHLAC, ISSN 1679-1061, № 27, p.222 -256, Ago./, Dez., 2019. http://revista.anphlac.org.br 
a partir de 1971, tiveram importante impacto na redução das taxas formais de desigualdade racial ao agirem pela perspectiva de classe. Por outro, no entanto, sob o argumento da necessidade da unidade nacional frente ao imperialismo, houve considerável silenciamento das discussões a respeito das relações étnico-raciais.

Fred Halliday (1994, p. 139), em Rethinking International Relations, coloca em xeque a assertiva realista segundo a qual as dimensões internas ou atuações pessoais deveriam ser excluídas do estudo das Relações Internacionais e abrir espaço ao único ator que interessa ao jogo político internacional, o Estado. Importante lembrar que após a reformulação dos preceitos da Nova História Política, durante a década de 1980, as Relações Internacionais também foram observadas sob novos ângulos. Atualmente, é ponto comum entre os especialistas considerar as atuações externas de um país intrinsecamente ligadas à sua política interna e aos seus atores políticos estatais e/ou não estatais. Igualmente, o historiador Pierre Milza (1996, p. 365), no livro organizado por Rene Rémond, Por uma história política, destaca "a política interna dos Estados como uma das principais chaves de explicação do jogo internacional”.

Assim, investigar a relação entre a questão racial no interior da ilha de Cuba, o modo como o governo tratou o tema internamente e de quais maneiras o divulgou ao mundo por meio dos foros internacionais e veículos de comunicação oficiais é um exercício importante para desfazer pretensas linearidades entre essas duas esferas de atuação estatal. Nesse sentido, estreitar laços com negros norte-americanos, apresentar Cuba como um modelo de democracia racial, veicular isso nas páginas da revista Tricontinental e fortalecer redes intelectuais pelo Terceiro Mundo, são iniciativas que podem guardar ambiguidades que merecem a atenção dos pesquisadores.

A Tricontinental se apresenta como um caso interessante nesse sentido, inclusive em função de sua inserção dúbia no desenho institucional cubano: a revista é publicada pela OSPAAAL, que assume o status de organização não governamental, sediada em Havana, e cujo secretariado é composto por doze secretários - quatro representantes de cada continente - e um Secretário-Geral cubano. Nesse sentido, o governo goza de protagonismo na instituição e na revista Tricontinental, ainda que ambas falem em nome "dos condenados da Terra de África,

\section{CANPHLAC}

Revista Eletrônica da ANPHLAC, ISSN 1679-1061, № 27, p.222 -256, Ago./, Dez., 2019. http://revista.anphlac.org.br 
Ásia e América Latina"5. Se, por um lado, ressaltamos que africanos, asiáticos e latinoamericanos dos mais diversos países estão presentes nas páginas da revista e são seus assíduos colaboradores, por outro é fundamental reconhecer o peso que os cubanos muito provavelmente tinham na tomada das decisões editoriais.

É importante ressaltar que as discussões e vivências pelos marcadores raciais transpassam a história cubana e não foram nem inauguradas nem encerradas com a experiência de Castro no poder. Ada Ferrer (1999, p. 93-140), em Insurgent Cuba, identifica nas lutas por independência na segunda metade do século XIX as bases originárias de um nacionalismo cubano pautado pelo antirracismo a partir da luta unificada de negros, mulatos e brancos, mas cuja agenda de união vai perdendo forças no século seguinte para uma aparente contradição entre demandas antirracistas e naturalização de hierarquias de cor, fazendo o nacionalismo cubano ser marcado, de forma singular, por essas tensões ao longo de todo o século XX e XXI. De modo semelhante, em A Nation for All: Race, Inequality, and Politics in Twentieth-Century Cuba, Alejandro de la Fuente (2001, p. 337-367) coloca o tema da raça no centro da história cubana em todo o século XX ao fazer um histórico das práticas raciais e racistas nas políticas do país desde o estabelecimento da $1^{\text {a }}$ República, fazendo jus à defesa de Ferrer de que é preciso aprofundar no entendimento desse entrelaçamento entre identidade nacional e questões raciais ao longo da história da ilha. De la Fuente nega algumas premissas enraizadas na história cubana, como a supressão da agência negra após o massacre de 1912 e a inexistência do racismo pós1959. Ao contrário, o pesquisador demonstra a atuação dos afro-cubanos quando da liberação do sufrágio universal masculino, sua participação política no governo de Machado e de Fulgêncio Batista e o silenciamento da questão racial após a tomada de Havana em janeiro de 1959, para sua retomada após 1986. Apesar de haver ganhos inegáveis sobre a desigualdade a partir da nacionalização de moradias, escolas e locais de convivência e de trabalho, provas do investimento real em socializar as novas gerações numa em uma "nova ética de igualdade cega para as questões raciais" [a new egalitarian and color-blind social ethic] (DE LA FUENTE, 2001, p. 337), fora das tradicionais e bem demarcadas divisões entre público e privado que

\footnotetext{
${ }^{5}$ A compilação de textos publicados na revista Tricontinental publicada pela OSPAAAL, em parceria com a editora Ocean Sur, em 2006, se intitulava precisamente "Rebelión Tricontinental: las voces de los condenados de la tierra de Africa, Asia y America Latina”.
}

\section{CANPHLAC}

Revista Eletrônica da ANPHLAC, ISSN 1679-1061, № 27, p.222 -256, Ago./, Dez., 2019. http://revista.anphlac.org.br 
dividiam também brancos e negros, essas foram ações graduais e, de la Fuente defende, incapazes de reverter padrões de discriminação racial.

O modo como a raça e o racismo foram tratados em Cuba nos durante os primeiros anos da década de 1960 deixou marcas profundas no país e alimentou questionamentos de outros pesquisadores sobre a realidade étnico-racial. Silvia Miskulin (2008), por exemplo, demonstra como o governo cubano adotou uma postura incongruente em relação aos intelectuais negros em Cuba às vésperas do Congresso Cultural de Havana, em 1968. Primeiramente, foram chamados ao evento e posteriormente proibidos de participar, sob a afirmação de que não se toleraria sedição ou divisão do povo cubano em termos étnicos e acusações de que os intelectuais negros de planejavam um complô. A autora detalha as formas como eles foram impedidos de participar do congresso, sendo que alguns foram presos e perseguidos, como o cineasta Nicolás Guillén Landrián, expulso do Instituto Cubano de Arte e Industria Cinematograficos (ICAIC) e cujo filme, Coffea arábiga, foi censurado pelo governo. Anne Garland Mahler (2013, p. 119-173) discorre sobre o filme, bem como a censura a ele, ressaltando que, muito além das críticas a Fidel Castro - cujas imagens na obra são intercaladas com a música dos Beatles The fool on the Hill -, a obra oferecia ainda uma crítica contundente às relações raciais em Cuba e à forma como a desigualdade racial era perpetrada - ou pelo menos não era suficientemente combatida - pelo próprio governo revolucionário.

Na esteira interpretativa de de la Fuente (2001) e Miskulin (2008), o artigo escrito por Rodrigo Espina Prieto e Pablo Rodríguez Ruiz (2006) lança luz sobre o contemporâneo, afirmando que o racismo na Cuba atual foi comprometido pela conformação de um discurso político oficial pós 1959 que proclamava a igualdade e estigmatizava todas as formas de exclusão. Para a revolução ser bem sucedida em sua prática e em seu discurso, a unidade era premissa incontornável e admitir diferenças raciais abria flancos incômodos. Falar de desigualdade racial na década de 1960 significava desviar do que realmente importava, a unidade nacional, e isso deixou marcas na contemporaneidade. Assim, para Prieto e Ruiz (2006, p. 45), o racismo cubano seria um "racismo de pero", travestido em discursos de igualdade: No soy racista, pero... Tal discriminação teria inclusive uma materialização espacial, advinda das migrações internas provocadas pela crise dos anos 1990 na ilha. Os bairros conhecidos como "llega y pon” são bairros marcados pela pobreza e marginalidade, nos quais as questões

\section{CANPHLAC}

Revista Eletrônica da ANPHLAC, ISSN 1679-1061, № 27, p.222 -256, Ago./, Dez., 2019. http://revista.anphlac.org.br 
matrimoniais e sexualidade também estão dentro da lógica da dinâmica racial do país. (ROBAINA, 2006; FERNANDEZ, 2010)

Mark Sawyer igualmente afirma que raça em Cuba deveria ser compreendida como uma variedade de práticas e entendimentos postos em conflito. Casamentos interraciais e igualdade formal coexistem com crenças racistas da inferioridade de afrocubanos e sua propensão à criminalidade, por exemplo. "Discriminação inclusiva" [inclusionary discrimination] é o termo utilizado por Sawyer (2006, p. 1-34) para descrever a dinâmica racial dominante, referindo-se ao modo como cubanos negros são considerados parte da nação e parte do projeto revolucionário, ao mesmo tempo em que são renegados a um status de segundo plano. A explicação do autor para isso são os "Ciclos raciais", nos quais circunstâncias políticas podem tanto pavimentar o caminho para uma maior igualdade ou bloquear qualquer oportunidade de inclusão de afrocubanos em determinado contexto, além de alimentar a desigualdade no ambiente de trabalho ou na vida política e social, um argumento que também aparece nos trabalhos de De La Fuente.

Apesar do que dizem as pesquisas acadêmicas e a experiência cotidiana de afrocubanos na ilha, no entanto, Fidel Castro declarou - como parte da Segunda Declaração de Havana que o racismo em Cuba era assunto oficialmente resolvido em 1962! Em 1966, reiterou: “a discriminação desapareceu quando os privilégios de classe desapareceram, e isso não demandou muito esforço por parte da Revolução" (CASTRO apud DE LA FUENTE, 2001, p. 4). Para selar a legitimidade do novo governo em termos da retórica nacional anticolonial e antiimperialista, a ideia de existência da segregação racial não era cabível, daí o deslocamento da discussão do plano interno para o externo, em que encontrou interlocução no seio dos movimentos pelos direitos civis nos Estados Unidos e entre combatentes pelas lutas de independência nas colônias africanas.

Dois contextos influenciaram para tal abordagem: a negação e negligência do governo norte-americano em lidar com a demanda pelos direitos civis dos negros em seu território e a luta anticolonial na África a partir da década de 1960. Os EUA e o continente africano, em

\section{CANPHLAC}

Revista Eletrônica da ANPHLAC, ISSN 1679-1061, ํo 27, p.222 -256, Ago./, Dez., 2019. http://revista.anphlac.org.br 
especial Angola ${ }^{6}$, abriram margem para que o governo cubano explorasse a questão do racismo no plano internacional. Em 1965, por exemplo, cubanos e angolanos planejaram um ataque ao forte português na província de Cabinda, ao norte de Angola, a Operação Macaco. Piero Gleijesis (2003), em entrevista com os combatentes da época, tomou ciência de como a Conferência Tricontinental, planejada para o ano seguinte, determinava as ações cubanas no exterior. Em entrevista, um oficial cubano afirmou: "queríamos desferir um golpe pesado no inimigo. Assim, quando a conferência começasse, todos saberiam que as guerrilhas estavam lutando em Cabinda" (apud GLEIJESIS, 2003, p. 177). Na África, Cuba buscou se posicionar como líder da causa anticolonial, tanto por meio da ajuda militar quanto do discurso político (SAWYER, 2006, p. 61). As palavras de Fidel Castro em 1975 deixam evidentes a necessidade do internacionalismo:

Existe um campo revolucionário, existe um movimento revolucionário e existe o internacionalismo proletário. E se os imperialistas querem saber o que é o internacionalismo proletário, Angola é um magnífico exemplo (CASTRO, 1976, p. 14).

Naquele momento, Castro afirma que o envio de tropas de Cuba a Angola se justificava não só pelo internacionalismo revolucionário, mas também pelo caráter "latino-americano" e "latino-africano" do povo cubano, pois "parte importante do sangue cubano é sangue africano" (1976, p. 15), daqueles trazidos como escravizados pelos colonialistas.

Alejandro de la Fuente sugere que a "campanha internacional cubana de solidariedade para com povos negros oprimidos ao redor do mundo era encenada para uma audiência doméstica" (DE LA FUENTE, 2001, p. 296), buscando deixar claro aos cubanos que a sociedade na qual viviam era superior aos Estados Unidos da América, inclusive em termos de igualdade racial. Segundo Sawyer, Castro via uma opressão comum feita pelos EUA sobre a população afro-americana (nos EUA) e cubana, daí o racismo ser visto não como uma questão interna, mas como uma consequência do imperialismo ianque. $\mathrm{O}$ apoio ao movimento negro estadunidense, bem como aos movimentos de libertação nacional na África, tiveram papel significativo na articulação de uma política interna de unificação nacional. Desse modo, a política externa da

\footnotetext{
${ }^{6}$ Em 1975, Cuba enviou 20 mil homens para lutar ao lado da MPLA em Angola, contra os militantes da UNITA, apoiados pelo regime sul-africano. Graças à mediação cubana, a União Soviética também enviou armamento e apoio logístico a favor do MPLA. Segundo Mark Sawyer (2006, p. 61), Cuba chegou a enviar 50 mil soldados a Angola.
}

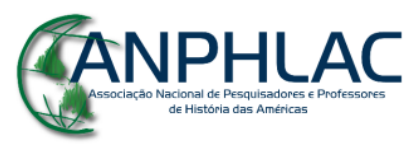

Revista Eletrônica da ANPHLAC, ISSN 1679-1061, N 27, p.222 -256, Ago./, Dez., 2019. http://revista.anphlac.org.br 
Revolução Cubana teria sido "usada para distrair a atenção dos problemas raciais domésticos" (DE LA FUENTE, 2001, p. 302).

De volta a setembro de 1960, ao bairro do Harlem, onde se alojou a delegação cubana, é preciso dizer que a decisão foi repleta de simbolismo - um bairro de ocupação negra, historicamente marginalizado, recebe Fidel Castro. De acordo com Besenia Rodriguez (2005, p. 62-87), a mudança se deu em virtude da exigência do Hotel Shelbourne, exclusiva à delegação cubana, de um pagamento adiantado de 10 mil dólares. A saída foi organizada por membros do Fair Play for Cuba Committee (FPCC) e líderes importantes do movimento pelos direitos civis, como Malcolm X, Robert Williams e Adam Powell manifestaram publicamente seu apoio ao líder cubano, junto às mais de duas mil pessoas que recepcionaram a comitiva no Harlem. A imagem de Castro como herói simbólico dos povos pós-coloniais e racializados se consolidou ali.

Curioso notar que a historiografia é unânime sobre os usos da questão racial como propaganda da política externa cubana, mas pouco se fala nos modos como esse discurso foi recepcionado e gerido na América do Norte. É Rodriguez (2005, p. 63) quem chama a atenção, por exemplo, ao pioneirismo da FPCC em enxergar ligações entre suas próprias realidades e o modelo cubano como projeto de sociedade a se alcançar, criando "uma linguagem antirracista de solidariedade que transcende a raça". Segundo a autora, toda uma geração de ativistas negros norte-americanos, anterior ao governo de Fidel Castro, inclusive, criou uma "esquerda norteamericana Tricontinental" e de "comprometimento com políticas transnacionais", cujos laços ideológicos se estendiam para África, Ásia, América Latina e Oriente Médio e desafiavam as múltiplas dominações estadunidenses no âmbito econômico, cultural e político.

A perspectiva da autora é importante para matizar a efetividade da política externa cubana, uma vez que já havia nos EUA um terreno fértil para a articulação entre os objetivos de Cuba e dos movimentos pelos direitos civis. Apesar de efêmera, a FPCC teve importância significativa diante do escalonamento das tensões entre EUA e Cuba na década de 1960. Alguns artigos da revista Fair Play, trabalhados pela autora, demonstram como os ativistas deixavam explícito seu entendimento da ligação entre as lutas dos negros norte-americanos e de Cuba. Em um artigo de autoria anônima denominado "Where Else Can an American Negro Go for a

\section{CANPHLAC}


Vacation? Why They Don't Want U.S. Negroes to Visit Cuba" justifica-se a razão dos impedimentos das visitas de negros norte-americanos à ilha:

Se o negro ainda não se sente em casa em sua terra nativa, depois de mais de trezentos anos no continente norte-americano, isso é parte da roupa suja da vida doméstica norte-americana e não deve ser vista pelos nossos vizinhos críticos (apud RODRIGUEZ, 2005, p. 66-67).

Essas interseções entre racismo e imperialismo foram exploradas à exaustão, é válido dizer, tanto pelos ativistas negros norte-americanos, que pressionavam o governo norteamericano para atender às suas demandas por igualdade e direitos civis, quanto por Cuba, com um triplo objetivo: fazer frente aos norte-americanos na Guerra Fria sobre a amplitude do termo democracia e igualdade, redirecionar possíveis descontentamentos internos sobre o tema e, por fim, construir-se como modelo internacional.

Raul Castro, na ocasião da mudança para o Harlem, declarou que "a verdade, a justiça, e a lógica da revolução cubana derrubaram as paredes de mentira..., ganhando os corações de 20 milhões de negros oprimidos nos Estados Unidos" (CASTRO apud MOORE, 1991, p. 79), tese que seria explorada ainda mais a fundo pela revista Tricontinental. Com certeza, a estada e a repercussão da delegação cubana em Nova York foi uma propaganda importante para o governo revolucionário e deu projeção internacional ainda maior para à ilha e para às intenções de Fidel Castro. Prova disso foi, por exemplo, o apoio massivo que Cuba recebeu das delegações africanas durante a XV Assembleia da ONU, à exceção da África do Sul sob o regime de apartheid. Segundo Carlos Moore, o encontro em Nova York em 1960 fortificou as conexões entre as arestas do triângulo América-África-Cuba, as mesmas que voltariam a ser fortalecidas sob a liderança cubana seis anos mais tarde, durante a Conferência Tricontinental e, sobretudo, nas páginas da sua revista homônima.

\section{O movimento por libertação negra nos Estados Unidos nas páginas da Tricontinental:}

Repeti minha declaração original: não tínhamos ido a Guadalupe em missão política. Simplesmente, achávamos que aquela era a maneira mais conveniente de retornar aos nossos países. Mas o homem não queria se acalmar. Começou a abrir algumas das caixas empilhadas no chão. Quando descobriu em uma delas exemplares da Tricontinental, um periódico revolucionário publicado em Cuba, ele me perguntou onde estava toda aquela literatura clássica em espanhol. Abriu outra caixa e, então, encontrou algo que o levou ao auge da raiva: cartazes que representavam Jesus Cristo,

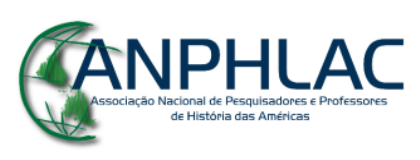

Revista Eletrônica da ANPHLAC, ISSN 1679-1061, № 27, p.222 -256, Ago./, Dez., 2019. http://revista.anphlac.org.br 
com uma auréola na cabeça, levando uma espingarda no ombro. Para ele, aquilo foi a gota d'água (DAVIS, 2018, parte IV, n. p.).

A seção anterior buscou demonstrar a amplitude e a complexidade das relações estabelecidas entre o governo cubano e o movimento negro estadunidense, situando-as em relação às políticas externa e doméstica de Havana. Uma biografia, livro publicado originalmente em inglês em 1974 e que serve de epígrafe para esta seção, inicia-se com os agradecimentos de sua autora, Angela Davis. Entre eles, a Fidel Castro e ao Partido Comunista de Cuba, "por terem me convidado a passar no país os meses necessários para trabalhar no manuscrito em tempo integral" (DAVIS, 2018, n. p.). O agradecimento, bem como o trecho acima, são demonstrativos: a intelectual descreve parte do percurso de retorno aos Estados Unidos após sua primeira estadia na ilha de Cuba, em finais dos anos sessenta.

O relato de Davis (2018) é bastante interessante na medida em que permite entrever uma série de elementos práticos dos esforços da solidariedade, e que tendem a ser negligenciados pela escrita acadêmica. Ao longo de todo o relato ficam evidentes os desafios enfrentados por muitos daqueles que queriam ver de perto a Revolução Cubana: bagagens eram revistadas em busca de material subversivo; passaportes e vistos eram questionados; uma viagem para Cuba era tratada como uma ameaça e as autoridades levantavam suspeitas (nem sempre infundadas) de que o indivíduo tinha recebido treinamento guerrilheiro ou se encontrava em missão comunista.

Tampouco é casual o fato de que na bagagem do grupo de Angela Davis se encontravam pacotes de edições da revista Tricontinental, cuja publicação em várias línguas, incluindo inglês, espanhol e francês, almejava alcançar o maior número possível de leitores ao redor do globo. O cartaz que levou o fiscal da alfândega a tamanho desconforto - a figura de Jesus Cristo portando uma espingarda, associando o imaginário cristão à guerrilha latino-americana ${ }^{7}-$ foi elaborado sob a direção artística de Alfredo Rostgaard nos escritórios da OSPAAAL, em Havana.

A viagem de Angela Davis não foi um evento isolado, mas se insere em um contexto de aproximação que havia se iniciado anos antes - consolidou-se a partir do episódio no Harlem e

\footnotetext{
${ }^{7}$ Consultado no arquivo de cartazes da OSPAAAL, em Havana. O documento também pode ser visualizado no site da organização. Disponível em: http://www.ospaaal.com/detail/o1_lg.html. Acesso em: 20 de maio de 2019.
}

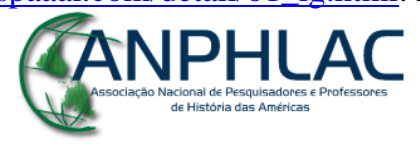

Revista Eletrônica da ANPHLAC, ISSN 1679-1061, No 27, p.222 -256, Ago./, Dez., 2019. http://revista.anphlac.org.br 
floresceu de maneira significativa nos anos sessenta, sobretudo a partir da Conferência Tricontinental. O combate ao racismo no plano internacional, encampado pelo governo cubano, contribuía para aumentar a visibilidade de consignas como o Black Power, de grupos como o Black Panther Party e dos movimentos anticoloniais e anti-imperialistas nos três continentes, sobretudo entre as esquerdas.

De acordo com Sarah Seidman (2012), esses trajetos foram representativos dos intensos contatos entre a ilha de Cuba e o movimento por libertação negra nos Estados Unidos, que nomeia de "rotas tricontinentais de solidariedade". A autora desenvolve um trabalho interessante ao analisar, mais especificamente, as relações entre a Revolução Cubana e o ativista Stokely Carmichael, nascido em Trinidad e Tobago e conhecido por sua atuação no movimento negro estadunidense. De acordo com Henrique Goulart (2019, p. 16), a trajetória do ativista pode ser compreendida em três fases distintas: uma primeira, em que esteve vinculado ao movimento por Direitos Civis e ao Student Nonviolent Coordinating Committee (SNCC), em prol de uma política de integração à sociedade estadunidense; uma segunda fase, marcada pela projeção de "uma identidade negra "nacional" assertiva e antagônica à norte-americana (branca)"; e, por fim, uma terceira fase de engajamento com referências latino-americanas, asiáticas e, principalmente, africanas. O discurso publicado pela Tricontinental que comentaremos nas páginas que se seguem corresponde sobretudo a esse terceiro momento, marcado pela maior aproximação do "terceiro-mundismo" e do pan-africanismo e pela mobilização de uma identidade negra transnacional e diaspórica (GOULART, p. 171-181). Em finais dos anos sessenta, Stokely Carmichael mudaria seu nome para Kwame Touré, em homenagem aos presidentes Kwame N'Krumah, de Gana, e Ahmed Sekou Touré, da Guiné. Nesse sentido, sua história de vida se entrelaça de modo significativo aos caminhos percorridos pelos movimentos, por libertação negra nos anos sessenta e setenta.

Efetivamente, a preocupação com o estreitamento dos laços entre o movimento negro estadunidense e as lutas anticoloniais e anti-imperialistas dos três continentes se expressava

\footnotetext{
${ }^{8}$ No caso das relações entre Carmichael e a Revolução Cubana, Sarah Seidman (2012) demonstra que foram marcadas por momentos não só de convergência, mas também de desacordos. Crítico das relações raciais na ilha, Carmichael se distanciaria cada vez mais de Cuba. Por outro lado, outras intelectuais estadunidenses teceram relações mais próximas com a revolução cubana. Esse é o caso de Angela Davis, como demonstramos anteriormente, e de Assata Shakur, que fora militante do Black Panther Party e hoje vive como asilada política na ilha.
}

\section{CANPHLAC}

Revista Eletrônica da ANPHLAC, ISSN 1679-1061, № 27, p.222 -256, Ago./, Dez., 2019. http://revista.anphlac.org.br 
antes da fundação da OSPAAAL e até mesmo da realização da Conferência Tricontinental. Havia consenso entre os membros do Comitê Preparatório da Conferência acerca da importância da luta contra o racismo no plano internacional, e isso transpareceu nos Antecedentes y objectivos del movimiento de solidaridad de los pueblos de Africa, Asia y America Latina, documento que foi prontamente distribuído às delegações presentes no início do evento. Naquelas páginas, discriminação e racismo foram apontados como "pilares ideológicos do colonialismo e de toda forma de exploração do homem pelo homem" (CONFERENCIA TRICONTINENTAL, 1966, p. 25) ${ }^{9}$.

As mais de oitenta delegações presentes na Conferência Tricontinental elaboraram duas resoluções acerca do povo estadunidense, aprovadas pelos delegados que atenderam à reunião. A primeira delas, intitulada Mensaje de saludo y aliento al pueblo de Estados Unidos, tecia elogios a todos aqueles cidadãos norte-americanos que se engajavam na crítica e no repúdio à Guerra do Vietnã. Em seguida, o foco se tornava a luta da população negra estadunidense contra o racismo. $\mathrm{O}$ desejo dos delegados reunidos em Havana era de

que o espírito de vitória e unidade no combate contra a reação chegue como alento
aos esforçados lutadores pelos direitos civis da população negra dos Estados Unidos,
que por séculos tem sido submetida a uma dupla discriminação e exploração por sua
condição social e pela cor de sua pele (CONFERENCIA TRICONTINENTAL, 1966, p.
73).

O texto se encerra manifestando repúdio à atuação da Ku-Klux-Klan e de outros grupos racistas no território norte-americano e exige "irrestrito respeito à vida da população negra dos Estados Unidos" (CONFERENCIA TRICONTINENTAL, 1966, p. 73). A questão foi abordada de maneira ainda mais específica na Resolución sobre los derechos humanos de los afronorteamericanos en los Estados Unidos, aprovada na mesma ocasião. O documento qualificava a "violência racista e brutal discriminação" como uma forma de "exploração do homem pelo homem" (CONFERENCIA TRICONTINENTAL, 1966, p. 73). Segundo a resolução, a população negra estadunidense tinha direito à legítima defesa equivalente àquela dos demais povos oprimidos que lutavam por libertação naquele período. Além disso, a resolução

\footnotetext{
${ }^{9}$ Esse documento foi, juntamente às resoluções aprovadas durante a Conferência Tricontinental, compilado em um livro de título homônimo editado pela OSPAAAL. O livro se encontra disponível para consulta na sede da organização, mas não está catalogado como parte do arquivo oficial. O conteúdo do livro será doravante citado dessa maneira.
}

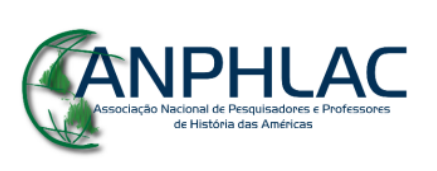

Revista Eletrônica da ANPHLAC, ISSN 1679-1061, No 27, p.222 -256, Ago./, Dez., 2019. http://revista.anphlac.org.br 
reconhece que as aproximações entre as lutas contra a opressão racial nos Estados Unidos e as demais lutas por libertação se tornam cada vez mais evidentes.

ainda que os afro-norte-americanos, geograficamente, não formem parte da América Latina, África ou Ásia, as circunstâncias especiais da opressão que sofrem e da luta que travam merece consideração especial e demanda que a Organização Tricontinental estabeleça os mecanismos necessários a fim de que esses irmãos na luta possam participar no futuro na grande batalha que travam os povos dos três continentes. (CONFERENCIA TRICONTINENTAL, 1966, p. 73)

É importante, portanto, observar a atenção especial dada ao movimento negro estadunidense já nesse período de formação e elaboração do desenho institucional da OSPAAAL. A Resolución sobre los derechos humanos de los afronorteamericanos en los Estados Unidos permite constatar que esse projeto político Tricontinental compreendia opressão, exploração e subordinação para além de um pertencimento estritamente geográfico aos três continentes. Além disso, questionava também os limites de explicações que se baseavam exclusivamente nas fronteiras nacionais. Desse modo, o documento abria caminho para a participação do movimento negro estadunidense na organização. As possibilidades expressadas pela resolução, por sua vez, foram habilmente exploradas por Stokely Carmichael. Inserido em um contexto da Política dos Encontros, o líder do Student Nonviolent Coordinating Committee visitava Cuba por ocasião da Conferência da Organización Latinoamericana de Solidaridad (OLAS) em 1967, quando elaborou o Tercer mundo, nuestro mundo (1967), publicado na primeira edição da revista Tricontinental.

Esse texto, um discurso que assume traços de um manifesto, responde diretamente a duas questões fundamentais: o que é o Terceiro Mundo? E qual papel os movimentos por libertação negra nos Estados Unidos desempenham em relação às lutas do Terceiro Mundo? De acordo com o ativista, o conceito de Terceiro Mundo, bem como a inclusão de "membros" em suas fileiras, deve se fundamentar no compartilhamento de condições de exploração. Nesse sentido, o autor reivindica para os negros estadunidenses um espaço nesse Terceiro Mundo, apontando a opressão e exploração colonial como sendo compartilhadas entre esse grupo e os povos de África, Ásia e América Latina.

Carmichael (1967, p. 18) define os Estados Unidos "como um enorme polvo, cujos tentáculos se estendem por todo o mundo, e cujo olho se encontra nos Estados Unidos. Cuba já lhe cortou um de seus tentáculos; Vietnã lhe amarrou outro [...]”. Essa constatação está ligada

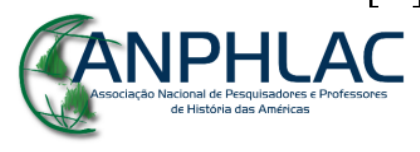

Revista Eletrônica da ANPHLAC, ISSN 1679-1061, № 27, p.222 -256, Ago./, Dez., 2019. http://revista.anphlac.org.br 
à ideia de que o capitalismo internacional operava como um sistema complexo de exploração e opressão, cujo combate deveria ser tão internacionalizado quanto os tentáculos daquele polvo. Aos negros estadunidenses competiria a tarefa de atacar o olho do polvo para, conjuntamente com a os povos dos três continentes, derrotá-lo. O autor chega a afirmar que "a mesma estrutura de poder que explora e oprime vocês, nos explora e oprime" (1967, p. 16).

Para além de sua dimensão anti-imperialista, o texto de Carmichael dialoga com a tradição crítica do pensamento radical negro, afirmando que a inserção do movimento negro estadunidense naquele grupo tinha raízes mais profundas. Para o autor, o pertencimento estava diretamente ligado à compreensão de que o tráfico atlântico de escravizados e a diáspora negra foram experiências históricas que entrelaçaram as experiências dos povos negros - não só nos Estados Unidos, aliás - de maneira muito mais complexa.

Black Power deve começar a falar especificamente à cultura dos homens de raça negra
em todo o mundo, devido ao fato de que as potências imperialistas violaram o
continente africano de uma forma tão covarde, sacando-nos de África e regando-nos
por todo o mundo; tirando-nos de nossa pátria; separando-nos de nossas mães e nossos
pais; saqueando nossa cultura, nosso idioma; roubando-nos nossa herança; e
despojando-nos de nossa dignidade. (CARMICHAEL, 1967, p. 19-20)

Carmichael não se limita a definir linhas de continuidade entre os negros estadunidenses e os demais povos negros do mundo, mas de fato busca tecer essas relações. Em seu texto, o pronome da primeira pessoa do plural, "nós", inicialmente utilizado para delimitar um "nós, os afro-americanos", começa a ser utilizado de maneira intercambiável e diluída, até que "nós" passe a significar não só a identificação com a população negra dos Estados Unidos, mas também um nós, "não brancos", “despojados”, “condenados da Terra”. O autor constrói ao longo do texto, portanto, a conclusão que está expressa no título de seu artigo: o Terceiro Mundo é o mundo daqueles explorados pelo sistema capitalista internacional, pelo imperialismo e pelo colonialismo; o Terceiro Mundo é o mundo de africanos, asiáticos, latino-americanos, e também dos negros estadunidenses.

E se os povos das distintas raças se unem - todos os que têm sido explorados pelo homem branco, sejamos nós chineses, índios ou negros - e uma vez que comecemos a compreender que NÓS formamos a maioria do mundo, e que o homem branco está em minoria nesse mundo, especialmente as potências brancas ocidentais, deixaremos de sentir temor do homem branco. (CARMICHAEL, 1967, p. 21)

\section{CANPHLAC}

Revista Eletrônica da ANPHLAC, ISSN 1679-1061, No 27, p.222 -256, Ago./, Dez., 2019. http://revista.anphlac.org.br 
Negros, "chineses", "índios" e todos aqueles que conformam a parcela "não branca" do mundo devem, para Carmichael, tomar consciência de seu espaço no cenário internacional, inclusive constituindo a "maioria do mundo". "As sociedades ocidentais brancas despojaram o mundo de sua humanidade. E é nossa tarefa nos unir a fim de salvar a humanidade do mundo" (CARMICHAEL, 1967, p. 21). Da união das distintas raças do mundo que foram exploradas pelo homem branco viria a transformação e ruptura radical com o sistema de exploração e opressão internacional capitalista, colonialista e imperialista.

A Tricontinental referenda tal postura em vários momentos de sua trajetória editorial, quando, por exemplo, decide divulgar a postura de Carmichael em reunião com líderes africanos de movimentos pela independência, em Dar-Es-Salaam, Tanzânia. A revista publica então a crítica de Carmichael aos líderes africanos que não apoiavam as lutas anticoloniais em outras partes do continente (TRICONTINENTAL, 1967 [2], p. 180) ${ }^{10}$. Esse é um momento singular que nos permite entrever uma estratégia do periódico, já que a interseção entre racismo, imperialismo e colonialismo se mostra presente pela fala de um negro ativista norte-americano, interlocutor preferencial aos intentos cubanos neste momento. A Tricontinental consegue divulgar, de modo sutil, sua própria bandeira, que muitas vezes se confunde com a do governo de Cuba. Essa posição sem dúvida faz seus préstimos às intenções maiores da política externa cubana, novamente misturando as camadas entre governo, imprensa e movimentos transnacionais e tricontinentais dessa história.

Enfim, é importante reconhecer aqui que Tercer Mundo, nuestro mundo de Carmichael foi o primeiro a definir o que se entenderia como "Terceiro Mundo" nas páginas da revista Tricontinental, e deliberadamente o definiu no primeiro número do periódico. No interior das oposições empregadas por ele, entre o homem branco e os "não brancos", o colonizador e o colonizado, subjaz a compreensão de um vínculo explícito entre colonização e raça, entre a luta contra o imperialismo e pela descolonização e a luta contra o racismo. Entre os textos do pensamento radical negro publicados no período e que ressaltam essa vinculação, vale citar a obra de Frantz Fanon. Ao examinar as relações entre raça e classe no contexto colonial, o autor afirma:

\footnotetext{
${ }^{10}$ A nota referendando a posição de Carmichael foi publicada sem atribuição de autoria, na seção de informes e notícias intitulada Tricontinental en marcha.
}

\section{CANPHLAC}

Revista Eletrônica da ANPHLAC, ISSN 1679-1061, No 27, p.222 -256, Ago./, Dez., 2019. http://revista.anphlac.org.br 
Este mundo dividido em compartimentos, este mundo cindido em dois, é habitado por espécies diferentes. [...] Quando se observa em sua imediatidade o contexto colonial, verifica-se que o que retalha o mundo é antes de mais nada o fato de pertencer ou não a tal espécie, a tal raça. Nas colônias a infra-estrutura econômica é igualmente uma superestrutura. A causa é conseqüência: o indivíduo é rico porque é branco, é branco porque é rico. (FANON, 1968, p. 29)

Um ano depois da contundente contribuição de Carmichael, o número 6 da revista Tricontinental contou com a contribuição de James Forman, importante líder do movimento pelos direitos civis dos negros norte-americanos. A publicação de Estados Unidos 1967: marea alta de resistencia negra ocorreu nos meses que se sucederam ao assassinato de Martin Luther King, ação descrita pelos editores da revista Tricontinental como "a atitude mais reveladora dos métodos, da violência irracional da contrarrevolução racista" (TRICONTINENTAL apud FORMAN, 1968 [6], p. 22). Meses após o falecimento de King, o cenário descrito era de crescente desilusão com as vias pacíficas e jurídicas. O artigo oferece um balanço da atuação do movimento negro estadunidense nas décadas de cinquenta e sessenta, traçando um panorama de sua expansão e radicalização. $\mathrm{O}$ forte caráter internacionalista e pan-africanista do texto se tornam evidentes quando o autor descreve o profundo efeito que líderes como Kwame N'Krumah e Ahmed Sékou Touré tiveram na consciência de jovens negros estadunidenses.

Nkrumah fazia sua entrada nas Nações Unidas: alto, negro e orgulhoso. Ahmed Sékou Touré, com seus olhos penetrantes, havia dito "não" a Charles de Gaulle. As imagens de homens negros em amplos trajes africanos, sentados nas Nações Unidas e atendendo os assuntos de seus governos, tiveram um profundo efeito na consciência desses meninos negros (FORMAN, 1968, p. 27)

O texto de Forman é também um manifesto, no qual o internacionalismo ganha destaque. De acordo com o autor, "trabalhar, lutar e morrer pela libertação de nosso povo nos Estados Unidos significa, portanto, trabalhar pela libertação dos povos oprimidos do mundo" (FORMAN, 1968, p. 23). O manifesto em questão interpela constantemente "o homem" [the man], empregando uma figuração discursiva utilizada no período para se referir ao governo dos Estados Unidos. Além disso, encerra-se com um ultimato.

Tu matou a demasiados dos nossos.

Tu matou a demasiada gente, ponto.

Te chegou a hora.

Nós queremos nosso mundo.

Nós; a gente negra de América Latina, Ásia e África!

(FORMAN, 1968, p. 24)

\section{CANPHLAC}

Revista Eletrônica da ANPHLAC, ISSN 1679-1061, № 27, p.222 -256, Ago./, Dez., 2019. http://revista.anphlac.org.br 
Entre os textos selecionados para publicação pelo corpo editorial do periódico, chama atenção um discurso proferido por Malcolm X (1969, p. 23-30) em dezembro de 1964, pouco antes de seu assassinato, em fevereiro do ano seguinte. $\mathrm{O}$ ativista retomava o movimento Mau Mau no Quênia, em franca apologia à conquista da liberdade por meio da força, caso necessário. De acordo com Manning Marable (2011, kindle, posição 23), Malcolm e suas palavras reverberavam entre a população negra urbana pois o ativista "era um produto do gueto moderno. A ira emocional que ele expressava era uma reação ao racismo em seu contexto urbano: escolas segregadas, moradias precárias, altas taxas de mortalidade infantil, drogas e crime". Além disso, Malcolm X questionava as próprias diferenciações estabelecidas entre norte e sul dos EUA, afirmando que os "racistas brancos do Norte estão em conivência com os racistas do Sul, só que os racistas do Norte sorriem na sua cara e mostram-lhe os dentes, e cravam-lhe a faca nas costas quando se viram.” (X, 1969, p. 26-27). Seu discurso se contrapunha de maneira direta aos movimentos e às lideranças negras que, naquele período, advogavam por integração e resistência não violenta. Malcolm se posiciona em defesa da violência revolucionária nos processos de libertação anticoloniais, reivindicando-a; de acordo com o ativista, a violência era o único idioma reconhecido pelo homem branco, ao que responde: "aprendamos seu idioma. Se seu idioma é o de uma escopeta, consigamos uma escopeta. [...]” (X, 1969, p. 26).

Muitos dos textos publicados pela revista Tricontinental enfatizaram a importância da auto-organização, ou seja, a defesa de que os movimentos pela libertação da população negra deveriam se organizar de maneira autônoma; geridos por pessoas negras e para pessoas negras. James Forman (1968, p. 31) afirma de maneira categórica que, a percepção em finais dos anos cinquenta, era de que "necessitávamos um movimento negro massivo, dirigido por negros e para negros". Anos depois, na edição de número 23, publicada em 1971, a Tricontinental publicaria uma entrevista com Charlene Mitchell, liderança do Partido Comunista dos Estados Unidos e uma das principais organizadoras da campanha internacional para libertar Angela Davis. Nessas páginas, a autora profere afirmações alinhadas às de Forman. Sua análise dos movimentos por igualdade racial nos Estados Unidos constata as limitações de estratégias adotadas anteriormente. A ativista é crítica à preponderância de jovens brancos na liderança de algumas ações iniciais do movimento pelos direitos civis. A cooperação com o Partido Democrata no início dos anos sessenta também encontrou entraves, já que o partido defendia o

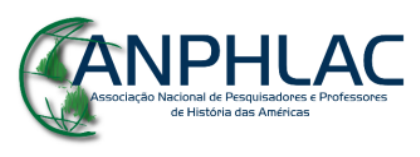

Revista Eletrônica da ANPHLAC, ISSN 1679-1061, № 27, p.222 -256, Ago./, Dez., 2019. http://revista.anphlac.org.br 
fim da segregação no Sul, enquanto que uma vez conquistado o direito de voto para a população negra, ofereceu pouco espaço para que o grupo pudesse lançar suas próprias candidaturas a cargos políticos. Charlene Mitchell afirmava, em consonância com tantas outras lideranças no período, que "se os negros iam se organizar, a organização deveria ser feita por negros" (MITCHELL, 1971, p. 123).

Explorando os limites encontrados nos Estados Unidos pelas iniciativas que buscavam cooperação, Mitchell evidenciava uma constatação incômoda: por mais importante e fundamental que seja a solidariedade, construí-la não é tarefa simples ou fácil. A formação de alianças demandava não só formação teórica, mas muita vontade política. Os impasses que a autora apresenta acabam por demonstrar as vantagens que a autonomia organizativa apresenta aos movimentos negros de que estes navegam águas, em tantos casos, turbulentas. Além disso, seu texto é um convite à reflexão sobre os limites explicativos de concepções como classe, raça ou nação, sobretudo quando tais categorias são pensadas de modo estático e isolado, ou seja, quando não se considera de que modo distintas formas de opressão e exploração interagem umas com as outras.

Peter Hammond escreve para a revista Tricontinental na mesma edição que Charlene Mitchell e lança explorações acerca da especificidade da questão racial em relação à classe. Rejeitando certas leituras marxistas, o autor afirma que "os negros nos Estados Unidos não são simplesmente outro grupo de trabalhadores como alguns de nossos amigos esquerdistas nos querem fazer acreditar" (HAMMOND, 1971, p. 68). O ativista busca compreender o modo como o racismo se articula à exploração econômica, produzindo "uma situação muito concreta de quase 40 milhões de negros nos Estados Unidos que compõem um subproletariado econômico e ao mesmo tempo estão racialmente oprimidos" (HAMMOND, 1971, p. 68). A abordagem defendida pelo autor não prescinde do pensamento marxista ou da categoria classe, como demonstrado pela citação acima, mas explora possibilidades de análise que consigam compreender de modo mais complexo as formas dinâmicas como classe e raça podiam operar de modo articulado.

A revista contou também com contribuições significativas de Huey P. Newton (1969, p. 100-104), Joudon Major Ford e George Murray (1969, p. 89-111), lideranças ligadas ao Black Panther Party. Além disso, a referência a imagens da Pantera Negra era um recurso imagético

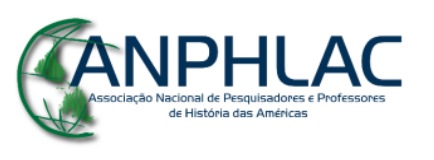

Revista Eletrônica da ANPHLAC, ISSN 1679-1061, № 27, p.222 -256, Ago./, Dez., 2019. http://revista.anphlac.org.br 
recorrente nos materiais gráficos desenvolvidos pela organização. Nesses textos, destaca-se o posicionamento em favor do direito de autodefesa armada e ganham especial força as consignas revolucionárias. Como parte da introdução à entrevista com Ford e Murray, o corpo editorial da Tricontinental afirma que o impacto do contexto internacional tinha sido fundamental para que a população negra dos Estados Unidos promovesse uma mudança qualitativa "extraordinária" em sua luta.

O triunfo da revolução cubana, há dez anos, há noventa milhas da primeira potência
imperialista, demonstrou que a presença do monstro, de perto, não impossibilita a
revolução. Quase simultaneamente e pela mesma época, as figuras de [Patrice]
Lumumba [no Congo], [Ahmed Sékou] Touré [na Guiné] e [Kwame] Nkrumah [em
Gana] se levantaram desafiantes e evidenciaram os anseios de liberdade de um
continente explorado durante séculos. Malcolm X predicava, então, que a luta contra
o racismo estava inevitavelmente unida à luta contra o colonialismo e o imperialismo.
Quase em uníssono Frantz Fanon escrevia sobre os "condenados da Terra", e Che
Guevara, que resumia suas experiências como guerrilheiro, punha ao alcance dos
explorados os métodos para sua libertação.
Estes fenômenos, aparentemente desconexos, criaram raízes nos elementos mais
determinados da população negra dos Estados Unidos e dando lugar a uma mudança
extraordinária em sua luta. Desde então, os afroamericanos têm aprendido que não
bastam as demandas por "direitos civis" (que significa acessar o nível de exploração
a que são submetidos os brancos explorados), e de que o que se trata é de lutar por
seus direitos humanos, de resgatar sua dignidade escamoteada. As demandas por
"integração", ontem, são sucedidas pela revolucionária consigna de "Black Power",
hoje. (TRICONTINENTAL apud FORD e MURRAY, 1969, p. 96)

Como demonstrado pela citação acima, as páginas da revista Tricontinental selecionaram seus interlocutores entre os ativistas do movimento negro estadunidense, privilegiando aqueles que adotavam um discurso mais sintonizado às pautas revolucionárias, uma tônica mais radicalizada e, sobretudo, um compromisso com a pauta internacionalista e anti-imperialista. Uma vez admitido esse recorte, a pluralidade de vozes e de organizações dos movimentos negros dos Estados Unidos que teceram diálogos e relações com a organização é digna de nota.

A OSPAAAL empreendeu esforços significativos para estabelecer conexões entre a luta pela libertação dos negros estadunidenses e o discurso radicalizado que florescia nos três continentes no período, sobretudo por meio da revista Tricontinental. Ao convidar líderes dos movimentos negros dos Estados Unidos para ocuparem o lugar de autores em suas publicações e divulgarem seu ponto de vista sobre sua própria situação, a revista formaliza a inclusão dessa parcela da população dos Estados Unidos no seu espectro discursivo e militante. Além disso,

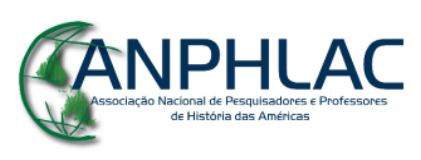

Revista Eletrônica da ANPHLAC, ISSN 1679-1061, № 27, p.222 -256, Ago./, Dez., 2019. http://revista.anphlac.org.br 
contribui para a ampla divulgação dessas lutas e do pensamento político de seus protagonistas, oferecendo espaço em uma plataforma de difusão de informação, teoria e cultura que se estendia por muitos cantos do globo. Amplia-se, desse modo, a tecitura das redes de solidariedade direcionadas pela organização.

\section{Sobre os Estados Unidos se lê e se vê: capas, contracapas e pôsteres da Tricontinental}

Além dos artigos, vale a pena discutir algumas das imagens em capas, contracapas e pôsteres publicados pela Tricontinental, que adicionam novos elementos ao discurso da revista. Uma vez que não representa a intenção deste artigo e dada a limitação de espaço para discussão teórica com o campo da cultura visual, optamos por trabalhar brevemente com essa documentação na medida em que ela contribui para a compreensão mais ampla do tema aqui abordado. Para cumprir com os objetivos deste artigo, selecionamos apenas quatro documentos dessa natureza. A capa da edição no 23 de 1971 traz como recurso visual a imagem de uma placa com os dizeres Home Sweet Home, uma expressão conhecida inclusive no Brasil em sua tradução direta para se referir ao ambiente doméstico de tranquilidade e segurança. A casa tranquila do Tio Sam, aqui representado com uma expressão risonha e alheia, no entanto, enfrenta uma ameaça interna que implode suas paredes, advinda - essa é a aposta da Tricontinental - do próprio interior de seu lar, doce lar.

\section{CANPHLAC}

Revista Eletrônica da ANPHLAC, ISSN 1679-1061, № 27, p.222 -256, Ago./, Dez., 2019. http://revista.anphlac.org.br 


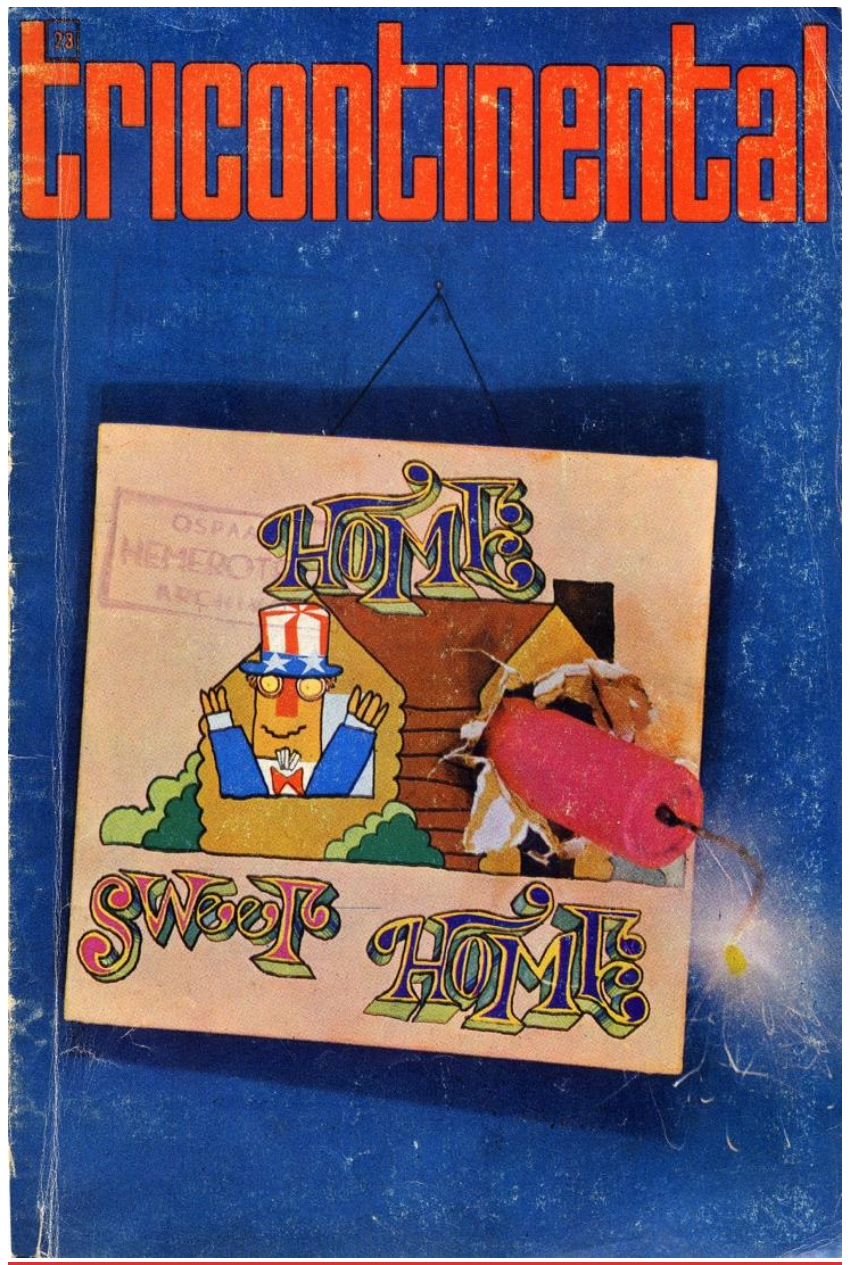

Figura 1: [Home Sweet Home].Capa. Tricontinental, Havana, n. 23, mar-abr, 1971.

A imagem dialoga também com uma expressão recorrente, que associa a condição da população negra dos Estados Unidos à situação de estar preso nas entranhas de um grande monstro. James Forman dialogou com essa figuração anos antes quando afirmava possuir "uma crescente compreensão de que vivemos nas entranhas do polvo" (FORMAN, 1968, p. 23). A confiança no potencial transformador das esquerdas estadunidenses e sobretudo do movimento negro - além do potencial autodestrutivo do imperialismo - fica ainda mais evidente quando analisamos o n. 23 da revista em sua totalidade. Visualidade e escrita se complementam com o artigo de Peter Hammond (p. 63-73), que traça percursos das lutas da juventude estadunidense, e com a entrevista da ativista negra e comunista Charlene Mitchell (p. 121-135), citados na seção anterior deste artigo. O título atribuído pelo corpo editorial da publicação à entrevista de Charlene Mitchell? En las entrañas del monstruo.

\section{GANPHLAC}

Revista Eletrônica da ANPHLAC, ISSN 1679-1061, Nº 27, p.222 -256, Ago./, Dez., 2019. http://revista.anphlac.org.br 


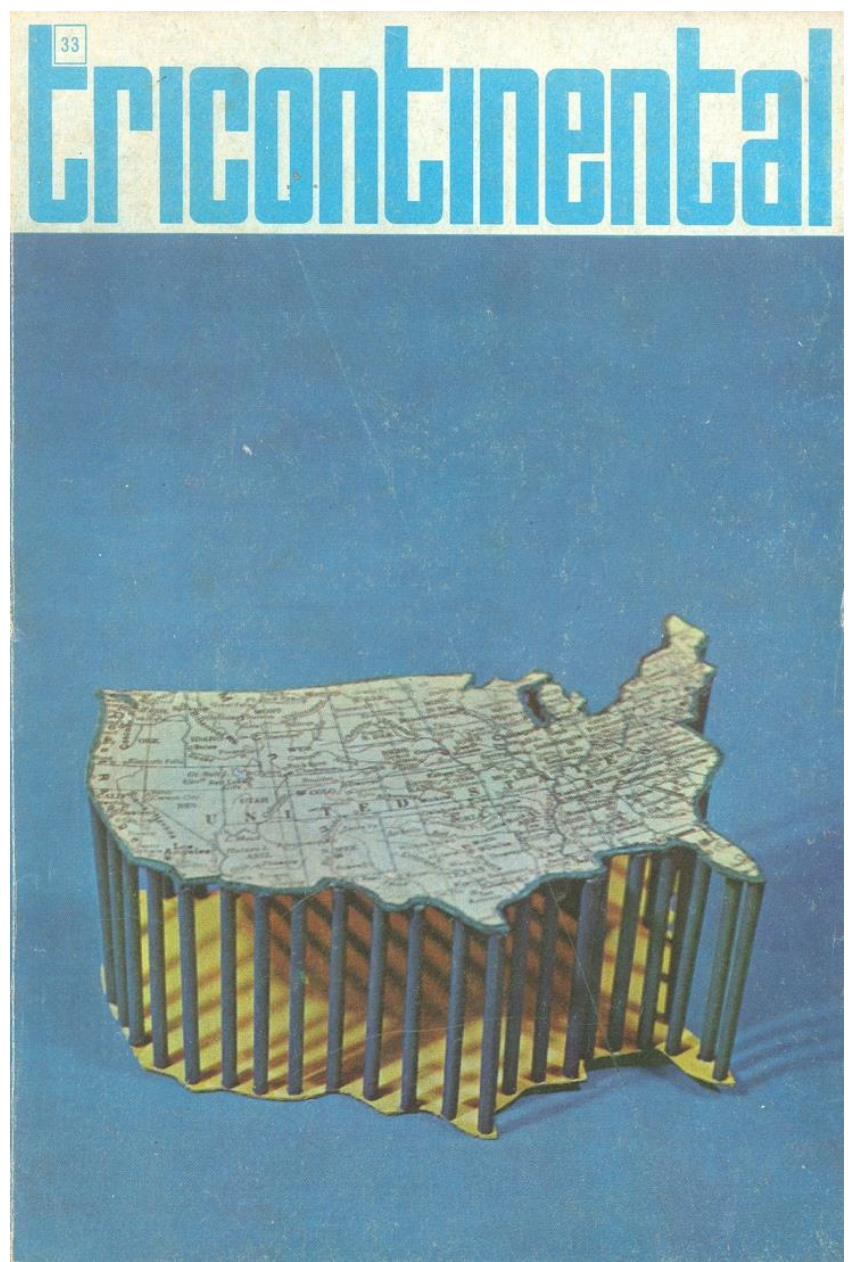

Figura 2: [Terra dos livres?] Capa. Tricontinental, Havana, n. 33, 1973.

Home Sweet Home não foi a única produção imagética da OSPAAAL a interagir de modo provocativo com os símbolos nacionais estadunidenses, como demostra a figura acima. Essa capa (Imagem 2) constrói sua mensagem interpelando o mapa dos Estados Unidos: uma prisão assume o formato do território do país, sobreposto por mapa envelhecido e circundado por um vasto azul celeste. A imagem parece ser uma irônica resposta a outro símbolo nacional. O hino dos Estados Unidos marcadamente repete, a cada uma de suas estrofes, que "a bandeira estrelada" [star-spangled banner] "tremulou", "tremulava", "tremulará" no céu da "terra dos livres e lar dos valentes" [land of the free and the home of the brave]. Enquanto a bandeira tremula no céu, por debaixo do mapa do país figuram as grades de uma prisão. O caráter envelhecido e antigo do mapa em questão passa a sensação de permanência, continuidade, uma

\section{GANPHLAC}

Revista Eletrônica da ANPHLAC, ISSN 1679-1061, Nº 27, p.222 -256, Ago./, Dez., 2019. http://revista.anphlac.org.br 
conexão direta entre o passado e o presente. As grades da prisão - símbolo contemporâneo da privação de liberdade - dialogam de maneira direta com o histórico escravocrata que também significou a negação de liberdade à população negra. Há algo de podre no reino da liberdade. Precisamente aquilo que se esconde sob o manto dos símbolos nacionalistas: a liberdade é um direito possuído por apenas uma parcela específica da população.

A imagem coincide com a ascensão das lutas contra o encarceramento em massa e em favor do abolicionismo penal. Enquanto a luta contra a segregação no sul alcançava importantes vitórias, as políticas racializadas de encarceramento em massa avançaram, principalmente sobre a população negra, atualizando práticas de segregação social e racial, restrição aos direitos constitucionais e privação de liberdade. O crescimento do encarceramento nos Estados Unidos durante os anos sessenta e setenta se tornava notável. O autor do artigo Cadenas Dobles, sob o pseudônimo de William Lee, foi categórico ao afirmar que "as prisões não reabilitam, não reformam, mas castigam, alienam e criam ódio. A prisão é uma experiência muito traumática e desumanizadora" (1973, p. 83). Essas páginas apresentam indícios significativos do viés racial das políticas de encarceramento: em uma das prisões analisadas no artigo, o percentual de negros e portorriquenhos entre a população carcerária chegava a $85 \%$ !

É significativo assinalar que ainda que as pessoas do Terceiro Mundo sejam $20 \%$ da
população dos Estados Unidos, constituem mais de $45 \%$ das prisões. Antes da recente
abolição da pena de morte pela Suprema Corte, trinta e seis estados mantinham cerca
de 600 prisioneiros no corredor da morte. Mais de $50 \%$ dos sentenciados eram negros
e do Terceiro Mundo. De 455 prisioneiros executados por estupro nos estados do Sul,
405 eram negros. De sessenta e um homens executados no estado da Georgia,
cinquenta e oito eram negros (LEE, 1973, p. 86).

Foi também nesse contexto que inúmeros dos ativistas, sobretudo negros, que recusaram o alistamento obrigatório na Guerra do Vietnã - [hell no, we won't go!] - foram encarcerados. Além disso, vários dos líderes de movimentos por libertação negra foram falsamente acusados de diversos crimes, entre eles Huey P. Newton, que era à época um dos principais líderes do Black Panther Party. Nenhum desses casos recebeu tanta atenção da comunidade internacional quanto a prisão de Angela Davis, acusada de conspiração, sequestro e assassinato em agosto de 1970. Davis foi inocentada de todas as acusações, não sem antes figurar na lista de fugitivos mais procurados pelo FBI, ser capturada e passar 18 meses presa aguardando o desenrolar de seu julgamento. À época, foi lançada uma importante campanha internacional sob a consigna

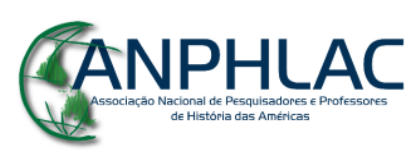

Revista Eletrônica da ANPHLAC, ISSN 1679-1061, № 27, p.222 -256, Ago./, Dez., 2019. http://revista.anphlac.org.br 
"Libertem Angela Davis!", que contou com a colaboração expressa do governo cubano e da OSPAAAL, ganhando forma no cartaz apresentado a seguir (Imagem 3). No centro da imagem a ativista emerge com os cabelos afro que se tornariam parte fundamental de sua representação estética, enquanto destrói as algemas que a prendiam. De acordo com a arquivista e colecionadora de cartazes Lisbet Tellefsen, "os cubanos enfocam a sua força. Ela está acorrentada, mas não destruída“" (TELLEFSEN apud MARKS, 2013).

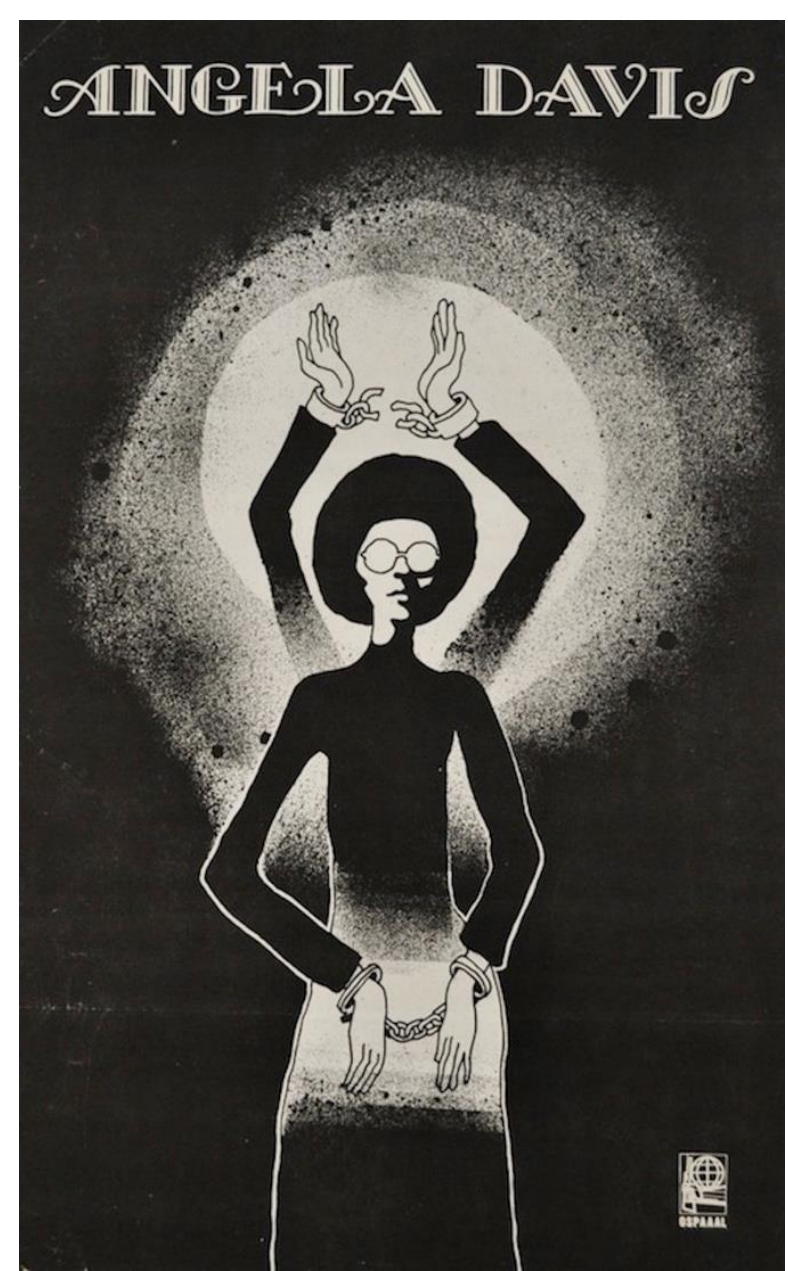

Figura 3: [Libertem Angela Davis] Il manifesto dell'OSPAAAL. Arte della Solidarietá. Havana e Roma: Editora Tricontinental e Il Papiro, 1997, p. 161.

A recorrência dos movimentos por libertação da população negra estadunidense nas páginas da revista, em textos e em imagens de destaque, em tantas edições ao longo dos anos, é um indício da importância dada pelo conselho editorial à divulgação desse tipo de temática para seu público leitor. O fato de a defesa da causa da população negra estadunidense não se

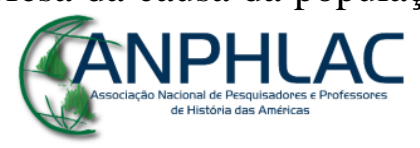

Revista Eletrônica da ANPHLAC, ISSN 1679-1061, N 27, p.222 -256, Ago./, Dez., 2019.

http://revista.anphlac.org.br 
restringir a textos escritos e incorporar tantos recursos visuais - capas, cartazes, fotografias, entre outros -, mostra que há também a intenção de um convencimento imagético-discursivo, que investe em oferecer esse tipo de material ao seu público leitor global.

Durante o período analisado neste artigo, os cartazes da OSPAAAL eram produzidos em conjunto com o Instituto Cubano de Arte e Industria Cinematográfico (ICAIC), sob a direção artística de Alfredo Rostgaard, que muito provavelmente participava também da elaboração do projeto gráfico da revista. Sua distribuição se dava principalmente por meio do envio conjunto às demais publicações oficiais da OSPAAAL. Com o objetivo de ampliar o alcance dos cartazes, a maioria das legendas explicativas era adicionada em vários idiomas. O investimento em imagens de forte apelo estético, por sua vez, tinha como objetivo transcender as barreiras da linguagem escrita, produzindo material que pudesse alcançar leitores em todo o mundo, mesmo entre aqueles que não fossem letrados nos idiomas oficiais da organização.

A análise da produção imagético-discursiva da OSPAAAL permitiu constatar que esta atuou em conjunto com a produção escrita para a defesa do projeto defendido pela organização. O esforço se justifica, confirmando a afirmação de Ulpiano Meneses (2003) acerca da importância das fontes visuais como ferramentas para a reflexão histórica. Em certos casos, por outro lado, as imagens expressam percepções e projeções que dificilmente teriam sido datilografadas, como no caso do cartaz abaixo (Imagem 4).

\section{CANPHLAC}

Revista Eletrônica da ANPHLAC, ISSN 1679-1061, № 27, p.222 -256, Ago./, Dez., 2019. http://revista.anphlac.org.br 


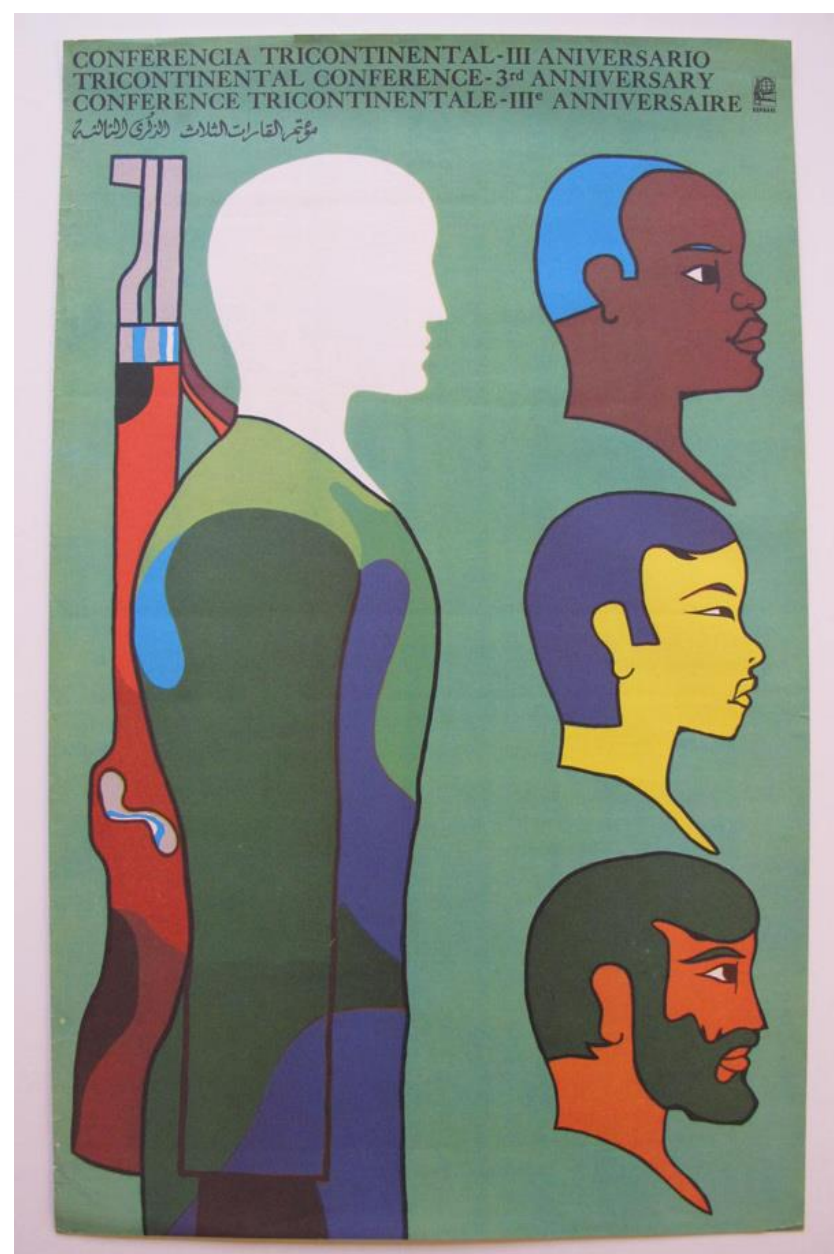

Figura 4: [Conferência Tricontinental - III Aniversário] Il manifesto dell'OSPAAAL. Arte della Solidarietá. Havana e Roma: Editora Tricontinental e Il Papiro, 1997, p. 180.

Assinado por Alfredo Roostgaard e distribuído em finais de 1968 e início de 1969, o cartaz acima celebra o terceiro aniversário da Conferência Tricontinental. Nele nos deparamos com uma narrativa visual da solidariedade tricontinental na qual a América se encontra representada pelo homem latino-americano. A presença das lutas por libertação negra nos Estados Unidos como parte integrante da solidariedade tricontinental não é expressamente mencionada, a não ser que o leitor associe o homem negro estadunidense ao busto que foi incluído na imagem para representar o homem africano. Sendo essa uma ausência ou uma coadunação, ficam evidentes as ambiguidades da longeva atuação da OSPAAAL, sujeita a escolhas autorais dos artistas e às contradições do discurso.

Nesse registro visual, destaca-se uma concepção territorializada de Terceiro Mundo, explicitamente vinculada aos três continentes, que contradiz algumas das afirmações presentes

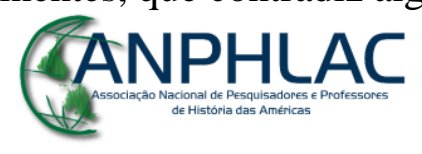

Revista Eletrônica da ANPHLAC, ISSN 1679-1061, No 27, p.222 -256, Ago./, Dez., 2019.

http://revista.anphlac.org.br 
nas páginas da revista, por exemplo. Percebe-se, além de uma óbvia concepção racialista fenotípica dos povos dos três continentes, que o molde em branco do guerrilheiro armado é compatível com as três partes, "as cabeças", do mundo. Ou quase, se olharmos de perto, o delineado em branco é compatível apenas com o guerrilheiro latino-americano, dados os formatos da cabeça e principalmente do nariz. Uma leitura possível para essa escolha de Roostgaard pode ser a defesa do protagonismo cubano na vanguarda das lutas de libertação internacional. Além disso, novamente aparece aqui a proposta de solidariedade e de guerrilheiros de várias partes do mundo lutando por uma única causa, em um só corpo. As diferenças de cada um seriam apagadas ou irrelevantes diante do uniforme camuflado, símbolo da defesa da luta armada. Diante desses impasses, esse cartaz encerra este artigo e é um convite aos historiadores que nos leem, para que assumam essas pontas soltas e continuem a tecer os fios dessas histórias tricontinentais.

\section{Considerações Finais}

Em entrevista ao jornal cubano Granma, Stokely Carmichael afirmou que a revista Tricontinental era "uma bíblia nos círculos revolucionários" (SEIDMAN, 2012, p.3). Como se buscou demonstrar neste artigo, a Organização de Solidariedade dos povos de África, Ásia e América Latina (OSPAAAL) - sobretudo por meio das páginas de sua revista oficial, a Tricontinental - atuou como mediadora e catalizadora das relações entre o governo cubano e o movimento por libertação negra nos Estados Unidos. Na medida em que a organização utilizou seu aparato institucional, publicitário e editorial para o fortalecimento desses laços, os documentos por ela produzidos conformam espaços privilegiados para o estudo desses contatos e conexões. Esse arquivo tricontinental é, sem dúvida, fascinante para quem busca compreender as trajetórias - ora convergentes, ora divergentes - das esquerdas, bem como a complexidade das alianças forjadas nesse período.

O caráter transnacional desse estudo, por sua vez, implica desafios próprios que foram respondidos por meio da alternância de escalas analíticas. Em um primeiro momento, o objetivo foi compreender de que modo o discurso oficial do governo sobre as questões raciais apresenta complexidades e contradições, sobretudo quando se empreende uma comparação entre o que é

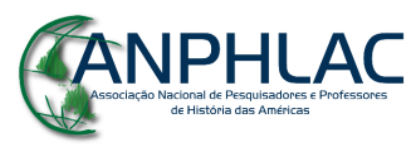

Revista Eletrônica da ANPHLAC, ISSN 1679-1061, Nº 27, p.222 -256, Ago./, Dez., 2019. http://revista.anphlac.org.br 
dito e feito na esfera doméstica e o que se apresenta como política externa. Nesse incômodo contexto, parte significativa da bibliografia sobre o tema defende que o apoio internacional do governo cubano à luta contra o racismo tinha como objetivo externalizar as tensões e conflitos raciais internos, como afirmam De la Fuente (2018) e Mahler (2018).

Nas seções seguintes, o foco passa mais especialmente às relações entre a OSPAAAL e os movimentos negros estadunidenses. O objetivo foi demonstrar como se formam as redes de solidariedade que permitiram ao governo cubano efetivar e fortalecer sua política externa. Nesse momento, cabe reconhecer o protagonismo cubano na atuação e funcionamento da OSPAAAL e publicação da revista analisada: Cuba foi responsável pela indicação do SecretárioGeral da organização e de parte significativa de seus funcionários, desde sua fundação até o encerramento de suas atividades, em junho de 2019.

As páginas da revista Tricontinental selecionaram seus interlocutores entre os ativistas pela libertação negra nos Estados Unidos. Aqueles que adotavam um discurso mais radical, revolucionário e internacionalista ganharam destaque precisamente por contribuírem para a construção do projeto político defendido. Havia pouco espaço para a defesa de propostas integracionistas em uma publicação que afirmava, entre seus objetivos, não só o fim do racismo, como a implosão do imperialismo - de dentro para fora dos Estados Unidos da América. Dito isso, uma relativa pluralidade de vozes figura entre as que se entrelaçaram às redes que a OSPAAAL tecia nas décadas de sessenta e setenta.

Os textos que chegam às páginas da publicação oferecem valiosas reflexões sobre os desafios da solidariedade: uma complexa leitura sobre as relações entre raça e classe; a defesa de que movimentos negros fossem dirigidos de maneira autônoma ou auto-organizada; a contundente resposta ao legado da diáspora africana e seus impactos na formação étnico-racial dos Estados Unidos - crítica que poderia facilmente ser estendida a muitos outros países do continente, inclusive Cuba. Esses posicionamentos divergem de modo significativo do discurso doméstico do governo cubano no período analisado. Nesse sentido, a leitura comparada e conectada proposta neste artigo permite identificar os momentos em que os discursos escapam a tentativas de homogeneização.

$\mathrm{O}$ discurso presente nas produções culturais analisadas nem sempre coincide com o discurso oficial do governo cubano, mas guarda, em relação a essas especificidades, distinções

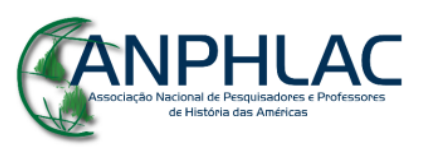

Revista Eletrônica da ANPHLAC, ISSN 1679-1061, № 27, p.222 -256, Ago./, Dez., 2019. http://revista.anphlac.org.br 
e particularidades. Como sugere Anne Garland Mahler (2018, p. 160-199), a produção cultural tricontinental pode ter oferecido elementos importantes aos afro-cubanos que teceram críticas à forma como o governo tratava as relações raciais na ilha - ainda que, na maioria dos casos, essas críticas tenham sido censuradas e reprimidas internamente. Além disso, ainda que reconheçamos o protagonismo cubano na OSPAAAL, a organização não deve ser descrita como mero instrumento nas mãos do governo cubano, sob o grave risco de se deixar de lado o caráter coletivo, abrangente e transnacional desse empreendimento.

A leitura detida das fontes nem sempre nos permite seguir uma linha contínua de análise e os resultados da investigação constantemente desafiam a vontade de encontrar coerências absolutas no passado. As conexões entre os ativistas dos movimentos negros norte-americanos e a Revolução Cubana ocupam papel essencial no intento de Havana em articular projetos governamentais internos e externos. Abrir espaço na revista Tricontinental para a divulgação dos ideais e lutas por libertação negra nos Estados Unidos foi muito provavelmente um empreendimento apoiado pelos muitos funcionários cubanos que trabalharam na instituição. Enquanto isso, certos trechos publicados assumem caráter quase que subversivo quando contrastados com a descrição oferecida pela bibliografia sobre as relações raciais em Cuba. Ultrapassando o debate acerca das motivações do governo cubano, o fato é que movimentos por libertação negra nos Estados Unidos participaram de maneira efetiva nas atividades da OSPAAAL e nas páginas da revista Tricontinental. Entrelaçar-se às redes de solidariedade política que estremeceram os anos sessenta e setenta, conectando movimentos políticos, partidos e governos dos três continentes, garantiu ao movimento negro estadunidense uma plataforma cujo alcance ia muito além das fronteiras da ilha.

Por último, este trabalho retorna ao presente. No dia 11 de junho de 2019, a OSPAAAL encerrou suas atividades como organização internacional depois de 53 anos em funcionamento. Por e-mail, comunicou "a las organizaciones miembros, fundadoras y amigas" o entendimento do governo cubano de que a organização cumpriu sua missão fundacional de acompanhar solidariamente as lutas dos países do Terceiro Mundo. O fim da OSPAAAL, como sua criação, é um marco não apenas na história cubana, mas das próprias conexões transnacionais. Afinal, as lutas tricontinentais chegaram mesmo ao fim?

\section{CANPHLAC}




\section{Referências Bibliográficas}

Black Panther [N/A]. Tricontinental, Havana, n. 2, 1967, sep-oct, p. 180.

CARMICHAEL, Stokely. Tercer mundo, nuestro mundo. Tricontinental, Havana, n.1, jul-ago 1967. p. 15-22.

CASTRO, Fidel; CABRAL, Luis; NETO, Agostinho; TOURÉ, Ahmed Sékou. Por el futuro de Africa. Tricontinental, Havana, n.48, mar-abr 1976, p. 9-16.

CONFERENCIA TRICONTINENTAL. "Antecedentes y objectivos del movimiento de solidaridad de los pueblos de Africa, Asia y America Latina"; "Resolución sobre los derechos humanos de los afronorteamericanos en los Estados Unidos"; "Mensaje de saludo y aliento al pueblo de Estados Unidos". In: Conferencia Tricontinental. Havana: Tricontinental, 1966. p. $5-34 ; 73$.

DAVIS, Angela. Uma autobiografia. São Paulo: Boitempo, 2018 [epub].

DE LA FUENTE, Alejandro. A Nation for All: Race, Inequality, and Politics in TwentiethCentury Cuba. Chapell Hill \& London: The University of North Carolina Press, 2001.

ESTRADA, Ulises (Org.). SUÁREZ, Luis (Org.). Rebelión Tricontinental: las voces de los codenados de la tierra de Africa, Asia y America Latina. Melbourne: Ocean Sur; Havana: Tricontinental; 2006

FANON, Frantz. Os condenados da terra. Rio de Janeiro: Civilização Brasileira, 1968.

FERNÁNDEZ, Nadine. Revolutionizing Romance: Interracial Couples in Contemporary Cuba. New Jersey \& London: Rutgers University Press, 2010.

FERRER, Ada. Insurgent Cuba: Race, Nation and Revolution (1868-1898). Chapell Hill/London: The University of North Carolina Press, 1999.

FORMAN, James. Estados Unidos 1967: marea alta de resistencia negra. Tricontinental, Havana, n. 6, mai-jun 1968, p. 22-52.

FORD, Joudon Major; MURRAY, George. Black Panther: el reto de los afroamericanos. Tricontinental, Havana, n. 10, 1969, jan-feb, p. 96-111.

GILDERHUS, Mark T. The Second Century: U.S.-Latin American Relations Since 1889. Maryland/EUA: Rowman \& Littlefield Publishers, 1999.

GILMAN, Claudia. Entre la pluma y el fusil: debates y dilemas del escritor revolucionario en America Latina. Buenos Aires: Siglo XXI, 2003.

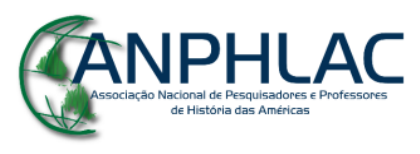

Revista Eletrônica da ANPHLAC, ISSN 1679-1061, No 27, p.222 -256, Ago./, Dez., 2019. http://revista.anphlac.org.br 
GLEIJESES, Piero. Conflicting missions: Havana, Washington and Africa - 1959-1976. The University of North Carolina Press, 2003, p. 177.

GOULART, Henrique Rodrigues de Paula. Entre os Estados Unidos e o Atlântico Negro: o Black Power de Stokely Carmichael (1966-1971). Dissertação (Mestrado) - Faculdade de Filosofia, Letras e Ciências Humanas da Universidade de São Paulo. Departamento de História. São Paulo, 2019.

GRONBECK-TEDESCO, John. The Left in Transition: The Cuban Revolution in US Third World Politics. Journal of Latin American Studies, 2008, n. 40, p. 651-673.

HALLIDAY, Fred. Rethinking International Relations. London: Macmillan Press, 1994.

HAMMOND, Peter. Los jovenes contra el sistema. Tricontinental, n. 23, mar-abr, 1971, p. 6373.

Il manifesto dell'OSPAAAL. Arte della Solidarietá. Havana e Roma: Editora Tricontinental e Il Papiro, 1997.

JAMESON, Frederic. Periodizing the 60s. Social Text, Durham, v. 9/10, p. 178-209, 1984.

LEE, William [pseudonimo]. Cadenas Dobles. Tricontinental, n. 33, 1973. p. 72-95.

MAHLER, Anne. Beyond the color curtain: Empire and resistance from the Tricontinental to the Global South. Tese de Doutorado - Emory University, 2013.

From the Tricontinental to the Global South: race, radicalism and transnational solidarity. Durham and London: Duke University Press, 2018.

MARABLE, Manning; AGARD-JONES, Vanessa. Transnational Blackness: Navigating the Global Color Line. New York: Palgrave, Macmillan, 2008.

. Malcolm X: a life of reinvention. New York: Viking (Penguin), 2011.

MARKS, Ben. Trailing Angela Davis, from FBI Flyers to 'Radical Chic' Art. Collectors Weekly, 03/07/2013. Disponível em: <https://www.collectorsweekly.com/articles/angeladavis-from-fbi-flyers-to-radical-chic-art/>. Acesso em: 20/10/2018.

MENESES, Ulpiano T. Bezerra de. "Fontes visuais, cultura visual, História visual. Balanço provisório, propostas cautelares”. Revista Brasileira de História. São Paulo, vol. 23, no 45, 2003, p. 11-36.

MITCHELL, Charlene. Una voz desde el monstruo. Tricontinental, n. 23, mar-abr, 1971, p. 121-135.

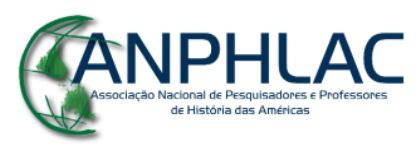

Revista Eletrônica da ANPHLAC, ISSN 1679-1061, № 27, p.222 -256, Ago./, Dez., 2019.

http://revista.anphlac.org.br 
MILZA, Pierre. Política Interna e Política Externa. IN: RÉMOND, René (Org.). Por Uma História Política. Rio de Janeiro: Editora UFRJ, 1996.

MISKULIN, Silvia Cezar. O ano de 1968 em Cuba: mudanças na política internacional e na política cultural. Esboços (UFSC), v. 20, p. 47-66, 2008.

MOORE, C. Castro, The Blacks and Africa.. Los Angeles: Center for Afro-American Studies. 1991.

NEWTON, Huey P. Cultura y liberación. Tricontinental, Havana, n. 11, mar-abr, 1969. p. 100104.

PRIETO, Rodrigo Espina; RUIZ, Pablo Rodríguez. Raza y desigualdad en la Cuba actual. Temas. $N$ 45: 44-54, enero-marzo de 2006.

ROBAINA, Tomás Fernández. Identidad Afrocubana: Cultura y Nacionalidad. Catauro: revista cubana de antropología. V. 8, n.9, 2006.

RODRIGUEZ, Besenia. "De la Esclavitud Yanqui a la Libertad Cubana": U.S. Black Radicals, the Cuban Revolution, and the Formation of a Tricontinental Ideology. Radical History Review, 2005 , n. 92 , p. 62-87.

SAWYER, Mark Q. Racial Politics in Post-Revolutionary Cuba. New York: Cambridge University Press, 2006.

SEIDMAN, Sarah. Tricontinental Routes of Solidarity: Stokely Carmichael in Cuba. Journal of Transnational American Studies, v. 4, n. 2, 2012.

Segunda Declaración de la Habana. Disponível em: <http://www.cuba.cu/gobierno/discursos/1962/esp/f040262e.html >. Acesso em: 22 de dezembro de 2016.

Solidaridad con los afroamericanos [N/A]. Tricontinental, n. 8, 1968, sep-oct, p. 138.

WALTZ, Kenneth N. Theory of International Politics. Long Grove, Illinois/EUA: Waveland Press, 1979

X, Malcolm. USA: la hora del Mau Mau. Tricontinental, n. 11, mar-abr, 1969. p. 23-30.

YOUNG, Robert. Postcolonialism: from Bandung to the Tricontinental. Historein, Athens, v. 5, p. 11-21, 2005.

2001.

Postcolonialism: an historical introduction. Hoboken: Willey-Blackwell,

\section{GANPHLAC}

Revista Eletrônica da ANPHLAC, ISSN 1679-1061, Nº 27, p.222 -256, Ago./, Dez., 2019.

http://revista.anphlac.org.br 